\title{
THE IMPACT OF MANAGEMENT QUALITY ON INNOVATION PERFORMANCE OF FIRMS IN EMERGING COUNTRIES
}

\section{Oleg Sidorkin}

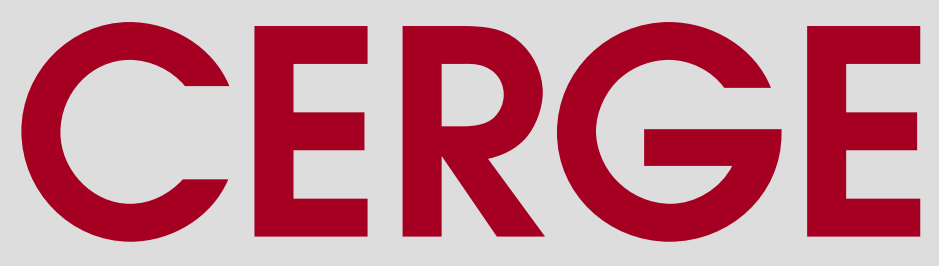

Cha res University

Centerfor Economic Research and Graduate Education

Academy of Sciences of the Czech Republic

Ec onomics Institute 


\section{Working Paper Series 555 (ISSN 1211-3298)}

\section{The Impact of Management Quality on Innovation Performance of Firms in Emerging Countries}

Oleg Sidorkin

CERGE-EI

Prague, December 2015 
ISBN 978-80-7343-362-8 (Univerzita Karlova v Praze, Centrum pro ekonomický výzkum a doktorské studium)

ISBN 978-80-7344-366-5 (Národohospodářský ústav AV ČR, v. v. i.) 


\title{
The Impact of Management Quality on Innovation Performance of Firms in Emerging Countries*
}

\author{
Oleg Sidorkin ${ }^{\dagger}$
}

\begin{abstract}
I study the impact of management quality on innovation input and output of manufacturing firms in ten emerging countries using data from the Management, Organization and Innovation (MOI) Survey. I find effects of management quality on the decisions of firms to invest in R\&D hold for both EU and non-EU emerging countries. An improvement in management quality from the 25th percentile to the median is associated with a 4.5 percentage point increase in the propensity to invest in R\&D and a 5.7 percent increase in R\&D spending per employee. Furthermore, there are positive but weak effects of management quality on product innovation. The empirical results for individual management practices show that the quality of monitoring management is intimately connected with innovation input and output. The quality of incentive management is related to higher input into innovation, but not to innovation output. The overall effects of operations and targeting management quality do not prove to be significant. All results hold after controlling for differences in management quality by industries. Additional analysis of management quality asymmetry shows that the results are driven mainly by firms with low quality management.
\end{abstract}

JEL codes: L2, M2, O3, P2

Keywords: management quality; R\&D; innovation; emerging countries

*Financial support from the Czech Science foundation (GAČR) project P402/10/2310 on 'Innovation, productivity and policy: What can we learn from micro data?' is gratefully acknowledged. The research contributes to the agenda Strategie AV21. I want to thank Martin Srholec, Jan Hanousek, Sasha Prokosheva, Helena Schweiger, Patrick Gaulé, Krešimir Žigić for valuable comments. All errors remaining in this text are the responsibility of the author.

${ }^{\dagger}$ CERGE-EI, a joint workplace of Charles University in Prague and the Economics Institute of the Czech Academy of Sciences, Politických vězňů 7, 11121 Prague, Czech Republic. Oleg.Sidorkin@cerge-ei.cz 


\section{Introduction}

Recent empirical studies have revealed a positive connection between management quality and innovation in a number of developed countries (Kremp and Mairesse 2004 Bloom et al. 2014a). However, the question of what types of individual management practices are especially important for innovation input and which types impact innovation output is still open. It is also not clear whether the effects of management quality hold for emerging countries. This paper helps to close this gap. I study how differences in overall management quality and the quality of management practices affect decisions of firms to invest into innovation input, i.e. to start searching for new solutions (R\&D propensity), to accelerate their efforts (R\&D intensity) and, eventually, to generate innovation output, i.e. introduce innovative products. I confirm that in emerging countries, management quality is positively connected to both innovation input and output. I also find that the quality of incentives and monitoring practices plays an important role in starting innovations and boosting innovation efforts, while only the quality of incentive practices is associated with better product innovations. As noted, management literature has established interconnection between management and firms' innovation. Scholars consider management one of the components of organizational capabilities that allow firms to achieve innovation successes. Teece (1986) points out the importance of complementary assets and capabilities as pre-requisites for successful product innovation and subsequent new product commercialization. The author highlights the role of capabilities in production of new products and in extraction of rents from innovation. Teece also suggests that the availability of these complementary assets and capabilities is crucial for promoting innovation efforts. Hayes, Wheelwright, and Clark (1988) argue that innovation depends on understanding of production and management processes specifically, such that better understanding of the processes 
are associated with innovation success. Teece and Pisano (1994) point out that if firms aim to support innovations, they need to re-structure their organizational and managerial processes, so that it can promote new technologies. Researchers point out that individual management practices, such as inputs management, knowledge management, strategic management, organizational culture, and others are essential for innovative firms (see Adams, Bessant, and Phelps (2006) for an in-depth review of different management measures). Teece and Pisano suggest several components of organizational and managerial processes which are important for my analysis. The authors point out that learning helps firms to achieve tasks related to innovation 11 Learning practices can facilitate problem solving in product production and operations. These practices can be influential, supporting introduction and production of new products, especially in cases of radical innovations. Teece and Pisano also argue that the organizational processes provide incentives connecting individual or team behavior and innovation and rewarding high performance. As a result, we should expect a strong empirical connection between incentive management and innovations. In cases where a performance reward system is established, we should also find a connection between management practices that monitor individual and team performance and innovation output. Griffin and Hauser (1996) point out that innovation processes ( $R \& D$ efforts) prefer orientation on long-term goals and that different functional departments work well if they have a similar time horizon. As a result, management practices supporting long-term goals could be beneficial to a firm's innovation success. Now I can lay down two main mechanisms that connect management quality and innovation output on one hand and management quality and innovation input, on the other hand. First, there is a direct influence of management on innovation output through the individual com-

\footnotetext{
${ }^{1}$ Continuous improvement, as well as Just-in-Time and Total Quality Control systems are examples of learning practices which have helped Japanese carmakers to achieve advantages in product development over their American and European competitors (Clark and Fujimoto 1989: Liker 2004)
} 
ponents of organizational and management processes. These processes support new technologies, new ideas, learning, solving problems, achieving results, aligning corporate goals and others. We can proxy a number of these individual components with relevant management practices that provide incentives, monitor performance, support long-term goals through targeting and help to improve production with operation management. Second, there is an indirect connection between management and innovation input, such as R\&D propensity and efforts. In other words, firms with better management practices, which help them to produce and commercialize products, are more likely to start and boost innovation in the first place. Empirical research on individual innovation management practices is a challenging task and scholars often focus on their presence (adoption) and quantifiable outcomes. Studying the quality and interconnection between different practices is important, but particularly difficult because of their complex qualitative nature: improvement of individual management practices is itself an exploratory development which influences firms' innovation performance (Birkinshaw, Hamel, and Mol 2008). Scholars analyze organizational and managerial factors that influence new product development both from a theoretical perspective (see Montoya-Weiss and Calantone (1994) and (Van der Panne, van Beers, and Kleinknecht 2003) for the relevant reviews) and in relation to individual firms (see Helper and Henderson (2014) for a discussion of management practices in General Motors and Liker (2004) in Toyota). These factors usually include management characteristics, such as management style, workforce management, performance management and others. New management practices can be developed by innovating firms from scratch or adopted from a large pool of existing innovations (Mol and Birkinshaw 2009; Walker, Damanpour, and Devece 2010). For example, (Hamel 2006) and his colleagues identified 175 innovative management practices in the 20th century, such as scientific management (time and motion studies), cost accounting and variance analysis and many others. Firms 
can also improve the quality of existing management practices to achieve higher performance results (Schweiger and Friebel 2013). There is a set of management practices that have been shown to be beneficial for a firm's performance, such as quality and environmental certification (Bloom and Reenen 2006). Kim, Kumar, and Kumar (2012) show that quality management has both direct and indirect positive effects on different types of innovations. Bloom et al. (2014a) and Bloom et al. (2014b) found a positive connection between management quality, based on individual practices, and innovation input (R\&D) and output (patenting) using two different large-scale management surveys. Makri, Lane, and Gomez-Mejia (2006) find that CEO incentives are tightly linked to desirable innovation outputs (both in quantitative and qualitative terms) for firms that are actively innovating. Moreover, they find that incentives that explicitly rely on the desired innovation outcomes help firms to achieve better market performance. Lerner and Wulf (2007), who confirm a positive relationship between long-term compensation plans for R\&D managers and innovation output, also support this result. At the same time, they find no relationship between long-term incentives for other executives who are not directly involved in innovation and innovation output. The effects of different management practices may differ by firm, industry and country characteristics. For example, innovative industries focus more on people management, motivation and incentives, while capital-intensive industries pay attention to monitoring and targeting Bloom et al. 2014b). Bloom, Schweiger, and Van Reenen (2012) found that the positive effects of management quality on firms' performance hold for emerging countries. Further studies are necessary to confirm whether the quality of individual management practices have sizable effects on innovation input and product innovation in emerging countries, once we control for other conditions traditionally considered in the empirical literature on this topic, such as technological capabilities, opportunities, trajectories and others (Trott 2008). The structure of the paper is as follows. 
Section 2 outlines the empirical model. Section 3 describes the dataset, key management measures and data patterns. Section 4 presents empirical results and prospects for future research. Section 5 provides concluding remarks.

\section{Model}

The empirical model to be estimated is as follows:

$$
\begin{aligned}
\text { R\&Dprop } i c & =\alpha_{1} l_{i c}+\beta_{1} k_{i c}+\gamma_{1} M_{i}+\delta_{1} Z_{i c}+u_{12 i c} \\
R \& D_{i c} & =\alpha_{2} l_{i c}+\beta_{2} k_{i c}+\gamma_{2} M_{i}+\delta_{2} Z_{i c}+u_{12 i c} \\
y_{i c} & =\alpha_{3} l_{i c}+\beta_{3} k_{i c}+\gamma_{3} M_{i}+\delta_{3} Z_{i c}+\theta_{3} R \& D_{i c}+u_{3 i c}
\end{aligned}
$$

where $R \&$ Dprop $_{i c}, R \& D_{i c}$ - are measures of innovation input (R\&D propensity and R\&D intensity respectively) and $y_{i c}$ output (new products introduced) of firm $i$ in country $c, l_{i c}$ - the logarithm of labor, $k_{i c}$ - the logarithm of capital; $M_{i}$ - the measure of management quality (aggregate quality of management and four different management practices); $Z_{i c}$ - other control variables which affect innovation, such as workforce characteristics (share of employees with university degrees and the average weekly hours worked), firm characteristics (firm age and whether it is listed on a national or international market), a set of two-digit industry, country and year dummies in which interviews were conducted $(2008,2009,2010), u_{12 i c}, u_{3 i c}$ - error terms. See Table 1 - Table 6 of the Appendix for a complete set of variables with summary statistics. I use two model specifications:

1. I include only an aggregate measure of the management quality to test whether this variable is connected to different measures of innovation input and output.

2. I include quality measures for four individual management practices (operations, monitoring, targeting, incentives) to test their effects on innovation 
measures.

According to the design, model (1) is nested in model (2). I also provide formal tests, which compare different model specifications. It is necessary to note that the analysis can reveal only conditional correlations. Although a causal relationship between management quality and innovation indicators is likely to exist, it is not possible to control for possible endogeneity and to measure precise causal effects. In the empirical specification, I use control variables presented in Table 2. I use interactions between a dummy variable for EU vs non-EU countries and aggregate management z-scores to separate the effects of the management quality on innovation input and output variables for different groups of emerging countries (see Table 3 for a complete list of emerging EU and non-EU countries).

\section{Data}

An empirical study of the relationship between management and innovations is a challenging task, because large cross-country surveys covering both topics in detail are scarce. Recently, there have been a number of attempts to improve data collection on innovation (Mairesse and Mohnen 2010). Community Innovation Surveys (CIS) have helped researchers to study the innovation activity of European firms and some non-member nations (Canada, USA, and others). Although CIS does not include questions related to management quality, they cover a number of questions about the introduction of new business practices (organizational innovation). There are a number of empirical studies based on CIS data (see, for example, Mol and Birkinshaw (2009) who analyzed drivers of management changes based on the UK Innovation Survey). In this study, I will focus on a unique survey which contains data on management quality and innovation (input and output) in the context of emerging countries. In October 2008 - November 2009, the European Bank for 
Reconstruction and Development (EBRD) and the World Bank conducted a Management, Organization and Innovation (MOI) Survey, based on recommendations from works by Bloom and Reenen (2006, Bloom and Reenen (2010). The managers of about 1,400 firms from 10 emerging countries in Europe and the ex-USSR (Belarus, Bulgaria, Kazakhstan, Lithuania, Poland, Romania, Russia, Serbia, Ukraine and Uzbekistan) were interviewed face-to-face. The organizers conducted the survey in the Russian Far East between February and April 2010. The survey focused mainly on production and operation activities, which include four groups of management practices: operations, monitoring, targeting and incentives. Up to now, MOI has remained one of few datasetsthat allow researchers to study the relationships between management quality and innovation in emerging countries. The data consists of information from manufacturing firms with between 10 and 5,500 employees. For my research, I drop the 42 observations for sole proprietorship firms. It is likely that these firms have less focus on formal management practices, so including them in the dataset could bias the results for the overall sample of firms. All monetary values have been converted into constant 2005 international US dollars. Physical capital is one of the factors influencing a firm's performance, and it could be an important factor affecting innovation decisions (Crepon, Duguet, and Mairesse 1998; Mohnen and Hall 2014). As a result, the measures of physical capital (fixed assets per employee) and a firm's efficiency (return on total assets, ROTA), based on Bureau Van Dijk's Orbis database, are matched to the sample of completed MOI interviews. The matched dataset was provided by the EBRD. Unfortunately, it is not possible to match financial data for all MOI interviews, so, if I use these variables, my sample decreases by about $36 \%$. Therefore, I evaluate the trade-off between inclusion of capital and financial variables and extending the sample size for different empirical model specifications. In my sample, median value of fixed assets per employee in 2008 is USD 5.0 thousand constant 2005 USD. Firms that invested 
in R\&D have slightly higher median value of fixed assets (USD 6.7 thousand) than firms that do not (USD 4.5 thousand). The results of a non-parametric test on the equality of medians show that the difference between medians for firms which invest and do not invest in R\&D is statistically different from zero at a 5\% level (Pearson $\left.\chi^{2}(1)=4.8125\right)$. The median of return on total assets (ROTA) in the same year is 2.4. Although firms which invest in $\mathrm{R} \& \mathrm{D}$ have slightly higher ROTA, the results of the non-parametric test show that the medians are not significantly different at conventional levels (Pearson $\chi^{2}(1)=0.2527$ ). I use ROTA to control how effectively firms use their assets to generate earnings (the higher the value, the more effectively firms use their assets). An average firm in my sample has about 216 permanent full-time and part-time employees. Firm size is an essential parameter to control, as firms may benefit from economies of scale (Earl and Gault 2004; Huergo and Jaumandreu 2004). The average share of employees with higher education is $27.5 \%$, which is a measure of human capital quality. Employees serve as an internal source of knowledge, which has a positive impact on innovation outcomes (Dakhli and Clercq 2004: Elche-Hotelano 2011). Further, I control for firm's age (an average firm in the dataset is 32 years old), as newer firms tend to be more innovative (Huergo and Jaumandreu 2004). Further, I control for firm's legal status, as successful innovation may benefit from stable share-holding arrangements, which can provide incentives for top management and effectively delegate monitoring (Soskice 1997). About 26\% of the firms in my sample are share-holding companies with shares traded on the national or international stock markets. About $8 \%$ have foreign firms or individuals as their largest owners. Foreign-owned firms can often have lower innovation costs and higher R\&D efforts due to better access to new technologies, lower costs of financing and better organizational practices (Guadalupe, Kuzmina, and Thomas 2012). In addition, I control whether firms have high-speed internet connection at their premises, as one of the measures of technological capability (Kim 1997). Other 
variables include weekly working hours of permanent full-time employees to control for effectiveness of human resource management (Laursen and Foss 2003). I also control for firm location (whether a firm is located in a capital city) as geographical concentration is linked to knowledge externalities and availability of skilled labor, and therefore to innovation propensity (Audretsch and Feldman 1996). Market environment can be an important innovation driver, therefore I account for market competition with imports from abroad. I examine innovation input and output in terms of:

1. Decisions of firms to engage in $R \& D$ (that is whether a firm has invested in R\&D). In my sample about $38 \%$ of firms invested in $R \& D$ in the last complete fiscal year of the study.

2. Decisions of firms to accelerate research efforts - R\&D intensity ( $R \& D$ spending per employee). Among the firms that engaged in $R \& D$, the average amount invested was about USD 400 of constant USD 2005 per employee) in the last complete fiscal year of the study.

3. Innovation output as new products introduced over the last three years of the study (a binary variable). In my sample, on average about $70.8 \%$ of firms introduced new products over last 3 years. This share is higher for firms that invested in R\&D research (92.0\%), than those which did not (57.9\%). The difference in the means of these groups is significantly different from zero according to the two-sample t-test with equal variances $(\mathrm{t}=-11.3,830$ d.o.f.).

Following Bloom and Reenen (2006) and Bloom, Schweiger, and Van Reenen (2012) I group questions into four main categories: operations (one question), monitoring (seven questions), targets (one question) and incentives (three questions). The operations question aims to answer how firms deal with process problems. Monitoring questions reveal the use of production performance indicators. Targets questions 
cover setting of time targets. Incentives questions are related to employee reward, promotion and dealing with poor performance. The survey includes mainly closed questions. In case of monitoring, I drop one question, as it has a substantial share of missing values. The questionnaire has been tested in two pilot surveys in the USA and Ukraine, and in the UK before implementation in the MOI survey. The questions included in the analysis are presented in Appendix 1. Although in general the definition of "good" and "bad" practice can be subjective and may differ by countries, Bloom and Van Reenen, the organizers of the MOI survey, focus on practices which have a straightforward meaning, so that the quality of each practice can be revealed based on responses to the survey $2^{2}$ Following the suggestions of Bloom, Schweiger, and Van Reenen (2012) for the MOI survey, I assign scores to responses for each management question such that a higher score means higher quality of the management practice analyzed. Further, I calculate z-scores by normalizing scores for each question to mean zero and standard deviation on $\mathrm{f}^{3}$,

$$
z_{m_{i}}=\frac{m_{i}-\bar{m}_{i}}{\sigma_{m_{i}}}
$$

where $z_{m_{i}}$ is the z-score of a question $m_{i}$ in firm i, $\bar{m}_{i}$ is an unweighted average of a respective question across all countries; $\sigma_{m_{i}}$ is a standard deviation of a question across all countries. Second, the z-scores were combined into management practices as a non-weighted average:

$$
\bar{m}_{i, P}=\frac{1}{n_{m_{i, P}}} \sum_{m \in P} z_{m_{i}}
$$

\footnotetext{
${ }^{2}$ For example, for Incentives question R.7 "How do you reward this establishment's production target achievement?", management score and the quality of practice increases from "There are no rewards" ( "All staff is rewarded" (score $=0$ ). Other questions follow a similar logic; nevertheless, one might possibly think of other score combinations for quality increase.

${ }^{3}$ This is a standard way to calculate aggregate measures of management quality, widely used in other surveys, such as Management and Organizational Practices Survey (MOPS) and World Management Survey (WMS).
} 
where $\bar{m}_{i, P}$ is the unweighted average of questions, belonging to one of four management practices $P$ (operations, monitoring, targets or incentives) in firm $i ; n_{m_{i, P}}$ denotes number of observations. Further, I construct an aggregate measure of the management quality as a non-weighted average of all four practices.

$$
\tilde{M}_{i}=\frac{1}{4}\left(\bar{m}_{i, \text { operations }}+\bar{m}_{i, \text { monitoring }}+\bar{m}_{i, \text { targets }}+\bar{m}_{i, \text { incentives }}\right)
$$

Finally, I calculate the z-scores for $\tilde{M}_{i}$ to compare management practices across firms. If the value of the z-score is positive, it indicates management practice above average ("good" practice); the opposite is true for negative values ("bad" practice).

$$
z_{\tilde{M}_{i}}=M_{i}=\frac{\tilde{M}_{i}-\overline{\tilde{M}}_{i}}{\sigma_{\tilde{M}_{i}}}
$$

Essential summary statistics for the z-scores (aggregate and by different practices), country dummies, year dummies, two-digit industries dummies as well as other variables in the dataset, which I describe further on, are presented in Appendix Tables 2 6. Comparison of the aggregate management z-scores across the surveyed countries is present in Appendix Figure 2 .

As expected, most EU countries take higher values of the aggregate management z-scores than non-EU emerging countries. Surprisingly, Ukraine shows above average management quality and Lithuania is below average. Uzbekistan and Kazakhstan have the worst management score of all surveyed countries. For example, in EU countries the mean z-score is 0.168 (median $=0.270)$, while for non-EU emerging countries the average $\mathrm{z}$-score is -0.113 (median $=-0.001$ ). The difference in means is different from zero at a $1 \%$ level $(\mathrm{t}=-3.71)$. Therefore, in $\mathrm{EU}$ countries variations in management quality might have different effects than in non-EU countries, which have relatively poorer management. I would like to study these differences in my analysis. The diffusion of four management practices by firm size (small, medium, 
large, extra-large business) is depicted in Appendix Figure 3. I can see that, in general, management practices are positively connected to firm size. For very small firms, formal management practices are of lesser importance. As the size increases, it becomes more difficult for managers to have direct influence on day-to-day production processes, communication with external sources, innovation activities and other tasks. As a result, managers must rely on formal practices to manage the growing firm. This finding is in line with existing literature (Bloom et al. 2014a Kremp and Mairesse 2004; Earl and Gault 2004).

The diffusion of four management practices by R\&D propensity (No - do not invest in R\&D; Yes - invest in R\&D) and by introduction of new products ( No - no new products are introduced, Yes - new products are introduced) are presented in Appendix Figure 4 .

The chart suggests a positive connection between the quality of individual management practices and the decision of firms to invest in $R \& D$ as well as innovation output in terms of new products introduced, across all management practices. I can see that firms which invest in $\mathrm{R} \& \mathrm{D}$ and introduce product innovations have higher quality management practices. This observation is in line with Kremp and Mairesse's (2004) findings for French manufacturing firms. As a result, MOI data contains explicit patterns connecting management quality and innovation, which I would like to study in detail using an empirical model, described in the previous section.

\section{Results}

In this section, I present my findings of how management quality affects innovation for two basic specifications: aggregate management quality (models 1, 3, 5) and 


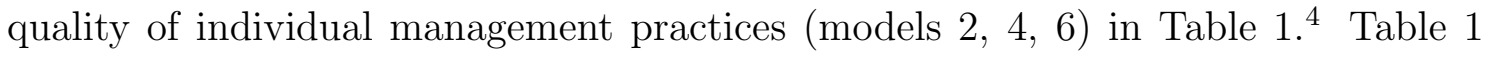
presents raw effects of the estimated model for R\&D propensity, R\&D intensity and introduction of new products. I find that $R \& D$ propensity strongly increases with the aggregate measure of management quality (model 1). That is, if the management z-score grows from the 25 percentile to the median value (which is equivalent to an increase in z-score from -0.67 to 0.12$)$, R\&D propensity increases by 4.5 percentage points (see Table 7, Model 1). A pairwise comparison of the estimated marginal zscores at 25 percentile and the median is statistically significant at a $1 \%$ significance level. If we keep in mind that the normalized z-scores of aggregate management quality range from roughly -4.0 to 2.0 for all firms in the data sample, the result is quite strong.

It worth noting that EU countries have higher R\&D propensity, however management quality has similar effects on R\&D propensity in both country groups, as the interaction term between EU dummy and the management quality is statistically insignificant at conventional levels (see Table 1, model 1). Figure 1 (left chart) demonstrates that the predicted probability of R\&D increases with management quality both for EU and non-EU countries; however, at the extreme values the estimates have wider confidence intervals.

Among individual practices (model 2 of Table 1) the quality of monitoring and incentives have strong positive effects, as expected. At the same time, the quality of operations and targeting practices have no statistically significant effects on R\&D propensity.

In MOI dataset, operations and targeting have the least variation among all

\footnotetext{
${ }^{4}$ After initial evaluation of statistical significance for fixed assets per employee and ROTA, I find that these variables are insignificant in innovation propensity and intensity equations, which is in line with the findings of Kremp and Mairesse (2004). As in their case, coefficients are similar when I both include and exclude these variables; at the same time, the effects of management are less significant and lower in magnitude. In the final estimation, I exclude fixed assets per employee and ROTA variables relying on a more parsimonious model and a larger sample. The estimates with fixed assets per employee and ROTA variables are available from the author upon request.
} 
Table 1: Management quality, normalized by management practices

\begin{tabular}{|c|c|c|c|c|c|c|}
\hline & \multicolumn{2}{|c|}{$\operatorname{logit}(\mathrm{R} \& \mathrm{D})$} & \multicolumn{2}{|c|}{ tobit $\operatorname{Ln}(\mathrm{R} \& \mathrm{D}$ spending $)$} & \multicolumn{2}{|c|}{ 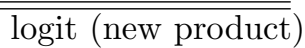 } \\
\hline & (1) & $(2)$ & $(3)$ & $(4)$ & $(5)$ & (6) \\
\hline Management z-score & $\begin{array}{c}0.272^{* * *} \\
(0.098)\end{array}$ & & $\begin{array}{c}0.058^{* *} \\
(0.029)\end{array}$ & & $\begin{array}{c}0.343^{* *} \\
(0.166)\end{array}$ & \\
\hline Operations z-score & & $\begin{array}{l}-0.047 \\
(0.088)\end{array}$ & & $\begin{array}{l}-0.008 \\
(0.030)\end{array}$ & & $\begin{array}{c}0.110 \\
(0.140)\end{array}$ \\
\hline Incentives z-score & & $\begin{array}{c}0.388^{* * *} \\
(0.134)\end{array}$ & & $\begin{array}{c}0.090^{* *} \\
(0.036)\end{array}$ & & $\begin{array}{c}0.029 \\
(0.213)\end{array}$ \\
\hline Targeting z-score & & $\begin{array}{c}0.043 \\
(0.081)\end{array}$ & & $\begin{array}{c}0.009 \\
(0.025)\end{array}$ & & $\begin{array}{c}-0.043 \\
(0.142)\end{array}$ \\
\hline Monitoring z-score & & $\begin{array}{c}0.338^{* *} \\
(0.145)\end{array}$ & & $\begin{array}{c}0.113^{* *} \\
(0.046)\end{array}$ & & $\begin{array}{c}0.453^{* *} \\
(0.209)\end{array}$ \\
\hline $\mathrm{EU}$ & $\begin{array}{c}0.644^{*} \\
(0.370)\end{array}$ & & $\begin{array}{c}0.294^{* *} \\
(0.127)\end{array}$ & & $\begin{array}{c}0.682 \\
(0.944)\end{array}$ & \\
\hline $\mathrm{EU} \times \mathrm{z}$-score & $\begin{array}{l}-0.068 \\
(0.168)\end{array}$ & & $\begin{array}{c}0.040 \\
(0.051)\end{array}$ & & $\begin{array}{l}-0.257 \\
(0.257)\end{array}$ & \\
\hline Ln(Labour) & $\begin{array}{c}0.330^{* * *} \\
(0.105)\end{array}$ & $\begin{array}{c}0.350^{* * *} \\
(0.105)\end{array}$ & $\begin{array}{c}0.036 \\
(0.032)\end{array}$ & $\begin{array}{c}0.039 \\
(0.032)\end{array}$ & $\begin{array}{c}0.296^{*} \\
(0.176)\end{array}$ & $\begin{array}{c}0.318^{*} \\
(0.175)\end{array}$ \\
\hline Higher education (share) & $\begin{array}{c}0.469 \\
(0.385)\end{array}$ & $\begin{array}{c}0.402 \\
(0.387)\end{array}$ & $\begin{array}{c}0.132 \\
(0.115)\end{array}$ & $\begin{array}{c}0.130 \\
(0.116)\end{array}$ & $\begin{array}{c}0.390 \\
(0.673)\end{array}$ & $\begin{array}{c}0.508 \\
(0.647)\end{array}$ \\
\hline Pressure from Imports & $\begin{array}{c}0.699^{* * *} \\
(0.181)\end{array}$ & $\begin{array}{c}0.669^{* * *} \\
(0.181)\end{array}$ & $\begin{array}{c}0.212^{* * *} \\
(0.055)\end{array}$ & $\begin{array}{c}0.198^{* * *} \\
(0.055)\end{array}$ & $\begin{array}{l}0.608^{* *} \\
(0.254)\end{array}$ & $\begin{array}{l}0.544^{* *} \\
(0.258)\end{array}$ \\
\hline High-speed Internet & $\begin{array}{c}0.738^{* * *} \\
(0.267)\end{array}$ & $\begin{array}{c}0.692^{* *} \\
(0.271)\end{array}$ & $\begin{array}{c}0.169^{* *} \\
(0.078)\end{array}$ & $\begin{array}{c}0.165^{* *} \\
(0.078)\end{array}$ & $\begin{array}{c}0.049 \\
(0.393)\end{array}$ & $\begin{array}{c}-0.002 \\
(0.389)\end{array}$ \\
\hline $\operatorname{Ln}(\mathrm{R} \& \mathrm{D}$ spending $)$ & & & & & $\begin{array}{l}6.560^{*} \\
(3.920)\end{array}$ & $\begin{array}{c}5.905 \\
(3.844)\end{array}$ \\
\hline $2009-2010$ & $\begin{array}{c}-0.492^{* *} \\
(0.196)\end{array}$ & $\begin{array}{c}-0.510^{* * *} \\
(0.198)\end{array}$ & $\begin{array}{c}-0.217^{* * *} \\
(0.064)\end{array}$ & $\begin{array}{c}-0.231^{* * *} \\
(0.066)\end{array}$ & $\begin{array}{c}-0.678^{* *} \\
(0.296)\end{array}$ & $\begin{array}{c}-0.722^{* *} \\
(0.303)\end{array}$ \\
\hline Constant & $\begin{array}{l}-2.665 \\
(3.444)\end{array}$ & $\begin{array}{l}-2.656 \\
(3.434)\end{array}$ & $\begin{array}{c}-3.142^{* *} \\
(1.228) \\
\end{array}$ & $\begin{array}{c}-3.169^{* *} \\
(1.239)\end{array}$ & $\begin{array}{l}-5.196 \\
(6.145)\end{array}$ & $\begin{array}{l}-3.919 \\
(6.082) \\
\end{array}$ \\
\hline Constant & & & $\begin{array}{c}0.486^{* * *} \\
(0.043)\end{array}$ & $\begin{array}{c}0.484^{* * *} \\
(0.043)\end{array}$ & & \\
\hline Country fixed effects & Yes & Yes & Yes & Yes & Yes & Yes \\
\hline Industry fixed effects & Yes & Yes & Yes & Yes & Yes & Yes \\
\hline Pseudo $R^{2}$ & 0.119 & 0.129 & 0.136 & 0.145 & 0.169 & 0.173 \\
\hline Prob $>C h i^{2}$ & 0.000 & 0.000 & 0.001 & 0.000 & 0.032 & 0.052 \\
\hline Observations & 834 & 834 & 699 & 699 & 387 & 387 \\
\hline
\end{tabular}

Standard errors in parentheses

Source: Author's calculations based on the EBRD and World Bank MOI survey.

${ }^{*} p<0.10,{ }^{* *} p<0.05,{ }^{* * *} p<0.01$ 
management practices, as each of them has only one underlying question, and, as a result, they depend heavily on exact wording. As discussed above, I expect that firms which effectively work on solutions to production problems are more likely to become innovators. The operation question in the MOI survey focuses on general handling of a wide range of problems in production processes (i.e. machinery breakdown, human error, etc.; see Appendix for further details). Although responses to this question could provide a good approximation of how firms solve operational problems, in fact $97.1 \%$ of answers (810 of 834) concentrate in two scores with the highest quality out of four. In both cases firms "fix it [problem] and take measures to make sure that it does not happen again". The difference in answers for these two scores comes from the "availability of a continuous improvement process to anticipate problems". As a result, the actual variation in answers might not be sufficient to reveal the quality of operation practices and their connection to innovation processes. As in the case of operation management practices, the model shows that target
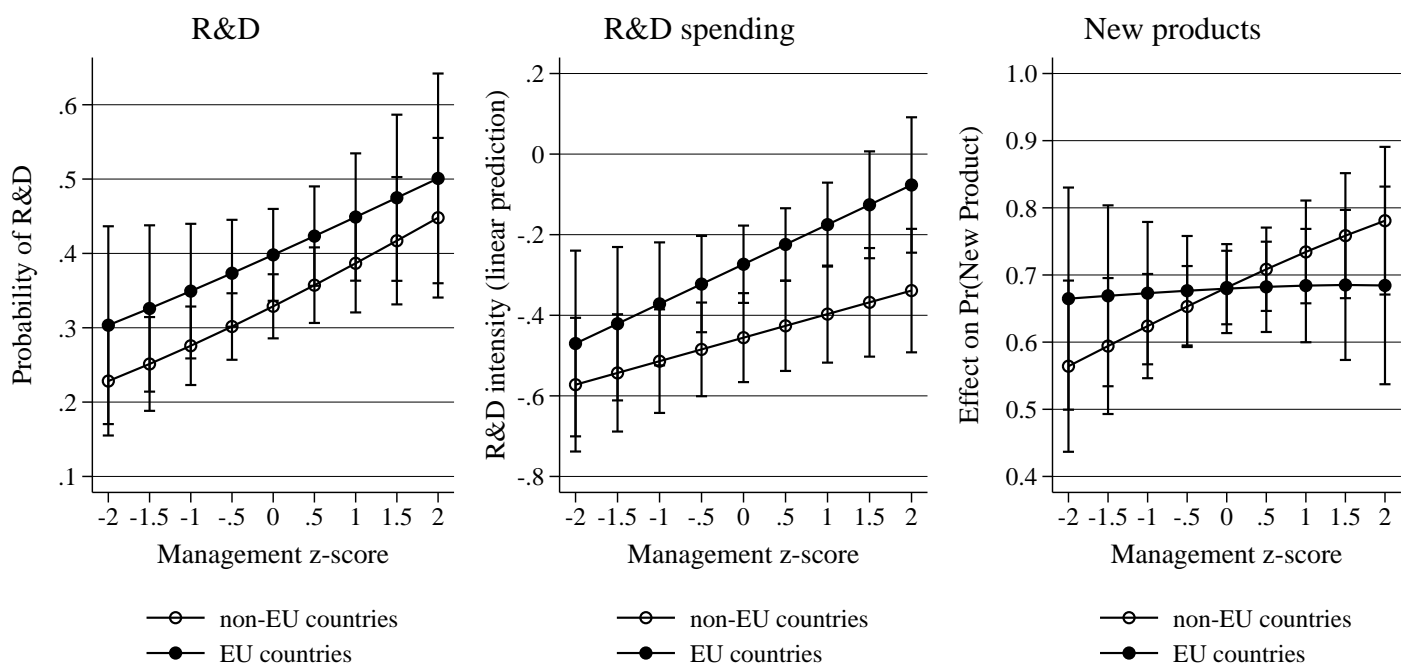

Figure 1: Predicted values of $R \& D$ propensity, $R \& D$ intensity and introduction of new products for different management z-score values

practices have no statistically significant effects on R\&D propensity. Although the survey question relates to the "production targets for its main product", it could 
be a good approximation of corporate goal-setting strategy. Further studies are necessary to confirm whether this result persists for developed countries or is a characteristic of emerging countries. For both model specifications, I find that firm size, quality of human capital, the quality of information technology and business practices (measured by the availability of high-speed Internet connection on a firm's premises) and market pressure from imports are positively associated with R\&D propensity. A formal Likelihood Ratio specification test that model (1) is nested in (2) suggests that I can reject this hypothesis at a 5\% significance level, and thus, model (2) is weakly preferred (see Appendix Table 8). In the next step I test the effects of aggregate management quality on $R \& D$ intensity (the amount firms spend on R\&D per employee) using a Tobit model censored at zero. I define R\&D intensity as logarithm of R\&D spending per employee in thousands of constant 2005 USD plus one. Table 1 (model 3-4) presents the results.

The aggregate management quality coefficient is positive and statistically significant at a 5\% significance level (model 3). An improvement of aggregate managerial quality from the 25 percentile to the median is associated with a $5.7 \%$ increase in the predicted amount of R\&D spending per employee (see Appendix Table 7, model 3). This effect is statistically significant at a $1 \%$ significance level. The overall result is consistent with a recent study by Bloom et al. (2014a) based on a survey of about 30,000 US plants, in which the authors suggest that establishments with higher management scores show significantly higher innovation activity measured by R\&D spending per employee. At the same time, I found no statistical difference in the effects for EU and non-EU emerging countries, as suggested by the respective interaction term. The predictive margin of $R \& D$ intensity for different values of management quality is depicted in Figure 1 (middle chart). R\&D intensity is positively connected to aggregate management quality both for EU and non-EU emerging countries, though the effects are somewhat stronger for EU countries. The 
pattern for emerging countries is similar to that of developed ones which exhibit strong and positive relationships between management quality and R\&D intensity (Bloom et al. 2014a).

If I look at individual management practices (model 4 of Table 1), their effects on R\&D intensity are similar to their impact on? R\&D propensity. Both monitoring and incentives coefficients are positive and significant at a $5 \%$ level. It is likely that the incentive component plays an important role, as the size and complexity of innovations grows along with $\mathrm{R} \& \mathrm{D}$ spending. In the MOI survey, incentives management has a wide definition and can be applied to business processes in general. Kremp and Mairesse (2004), for example, use a different set of questions to define knowledge management practices. One of these practices (incentive policy to retain employees), can be, in a wide sense, considered incentives management. The authors find that incentives have significant positive effects on both innovation propensity and intensity, which confirms my findings. Other management practices are not statistically significant from zero, indicating that they may play a more limited role in decisions about the amounts firms are willing to spend on R\&D. If I compare two model specifications when individual management practices are excluded (model 3) and included (model 4), the likelihood ration specification test suggests that model (4) should be preferred (I can reject the null hypothesis that model (3) is nested in model (4) at a $1 \%$ significance level (see Appendix Table 8).

In the next step, I consider whether management quality is associated with better innovation output: whether new products are introduced. I estimate models (5) and (6) by logit regression and present the results in Table 1. The effect of the aggregate management quality (model 5) is statistically significant at a 5\% level. It is worth noting that I do not find that emerging EU countries have higher innovation output than non-EU countries, as the EU dummy variable is not significant at conventional levels. The interaction term of management quality and the EU dummy is negative, 
indicating that in EU countries management quality and innovation output might have a negative connection, although the coefficient is not significant.

If I look at Figure 1 (right chart), which depicts the predictive margin of innovation output for different values of management quality, it suggests that although management quality positively affects probability of new product introduction, increasing management quality has a positive impact mainly in non-EU countries, while for EU countries the effects are negative. For emerging countries, if a firm at the 25th percentile of management quality distribution increased its management quality to the median level, this would lead to a 0.8 percentage point increase in the probability of new product introduction. At the same time, these effects are insignificant at conventional levels if all other variables are taken at their means (Appendix Table 7, model 5). If I look at the effects for non-EU countries only, the efficiency of management quality would be stronger ( 0.8 percentage points increase in the probability), but statistically insignificant (standard error is 0.06 , p-value $0.210)$.

If I look at individual management practices (model 6), I find that only monitoring management quality has a statistically significant effect (at a $5 \%$ significance level), while the coefficients of other management practices are not significant, despite being positive. This result is in line with Laursen and Foss s (2003) findings for a developed country. They studied the effects of human resource management practices on innovation output for Danish firms (some of these practices are related to incentives) and found that incentives have weak effects on the introduction of new products. A likelihood ratio specification test (see Appendix Table 8) cannot reject the hypothesis that model (5) is nested in model (6). Therefore adding the quality of individual management practices as predictor variables does not lead to an improvement in the model fit. I find that in all specifications, market pressure from imports play a sizable positive role, and the coefficient is statistically signifi- 
cant at $5 \%$ level. This result confirms earlier findings of the importance of perceived market competition for innovation output Kremp and Mairesse 2004: Mohnen, P. and Dagenais, M. 2002; Mohnen, Mairesse, and Dagenais 2006). Although I expected that the quality of all management practices would play an important role for new product introduction in emerging countries, I did not find support for this hypothesis in the empirical results for either EU or non-EU countries. Other factors, mentioned above, have much greater effects on innovation output than the quality of management practices, except incentives management.

\section{Industry z-score normalization}

It is possible to argue that measures of management quality might differ across manufacturing sectors. For example, the management quality achieved by top firms in certain sectors might be considered mediocre in others. If I look at management z-scores by industries (see Figure 5), these difference on average are not striking for maximum values (i.e. 'best' management quality), but are striking in terms of minimum values (i.e. 'worst' management quality). Some sectors, such as electronics, have relatively higher values. I would like to account for these differences and normalize scores by firms in each sector (2-digit code) separately. As a result, for questions in each management practice, equation 4, the nomalization will be as follows.

$$
z_{m_{i s}}=\frac{m_{i s}-\bar{m}_{i s}}{\sigma_{m_{i s}}}
$$

where $s$ is the sector in which firm $i$ operates. Then z-scores, aggregated for different management practices 7, are normalized by sector $s$ as well. That is, the definition of "good" and "bad" aggregate management quality is sector-specific.

$$
z_{\tilde{M}_{i s}}=M_{i}=\frac{\tilde{M}_{i s}-\overline{\tilde{M}}_{i s}}{\sigma_{\tilde{M}_{i s}}}
$$


Estimation results in Appendix Table 9, columns (1)-(6) show that main conclusions, described in detail in the previous section, hold both numerically and qualitatively when I take sector-specific characteristics of management quality into account.

\section{Quality asymmetry analysis}

In this section I study asymmetries in the relationship between management quality, R\&D and innovation output. For this purpose I use a piecewise regression to find whether low or high aggregate relative quality of management has a stronger connection to innovation. As management quality $M_{i s}$ is the main variable of interest, I use splines to distinguish between below (low) and above (high) mean management quality:

$$
\begin{aligned}
R \& \text { Drop }_{i s c} & =\alpha_{1} l_{i s c}+\beta_{1} k_{i s c}+\gamma_{11} M_{i s}^{-}+\gamma_{12} M_{i s}^{+}+\delta_{1} Z_{i s c}+u_{1 i s c} \\
R \& D_{i s c} & =\alpha_{2} l_{i s c}+\beta_{2} k_{i s c}+\gamma_{21} M_{i s}^{-}+\gamma_{22} M_{i s}^{+}+\delta_{2} Z_{i s c}+u_{2 i s c} \\
y_{i s c} & =\alpha_{3} l_{i s c}+\beta_{3} k_{i s c}+\gamma_{31} M_{i s}^{-}+\gamma_{32} M_{i s}^{+}+\delta_{3} Z_{i s c}+\theta_{3} R \& D_{i s c}+u_{3 i(1)}(1)
\end{aligned}
$$

where $M_{i}^{-}$is an indicator of low management quality, is equal to the measure of management quality for firm $i$ in a country $c$ when it is below average in sector $s$ and the value is equal to zero otherwise; $M_{i}^{+}$is an indicator of high management quality, which is equal to the measure of management quality when it is above average in sector $s$ and is equal to zero otherwise.

Results are presented in Appendix Table 10. In most cases, a positive relationship between management quality and R\&D holds only for firms with low quality management, and for this group the size of the effect is greater. At the same time, for firms with high management quality, the relationship is mixed and, in case of incentives management, even weakly negative (see columns (1)-(4)). If I look at the 
relationship between management quality and innovation output (columns (5)-(6)), the effect of management z-scores is statistically insignificant. This result suggests that this relationship might be weak and could be sensitive to the model specification and z-score interval under consideration. In general, asymmetry analysis shows that the relationship between management quality and innovation input is of high importance for firms with below average management quality, while firms with higher quality management might not enjoy innovation acceleration associated with better management.

\section{Conclusion}

This paper explicitly focuses on connections between the quality of aggregate management and individual management practices and innovation (input and output) in emerging countries. The empirical analysis presented in the paper helps to explain whether management quality, associated with firms' operations, affects R\&D propensity, R\&D intensity and introduction of new products. Using a large dataset of emerging EU and non-EU countries, this study provides evidence that better aggregate management quality is associated with a higher propensity of firms to invest in $R \& D$ and higher intensity of their R\&D spending. While the effects of management quality on introduction of new products are positive, this relationship is weak and improvement of management quality does not lead to a significant increase in the probability of new product introduction. As a result, although management quality does not guarantee the successful introduction of new products, it may have an indirect positive result through higher R\&D propensity and intensity. In emerging countries, the quality of monitoring and incentive management practices is especially important for $R \& D$ propensity and intensity. While the role of monitoring for new product introduction is weak, incentive management quality 
has sizable effects. This result holds after controlling for differences in management quality by industries. Quality asymmetry analysis strongly suggests that the relationship between management quality and innovation input is sizable for firms with low management quality, while for firms with high management quality it becomes statistically insignificant. As the study covers emerging countries, the findings may be of particular importance for emerging economies aiming to promote successful innovation. The MOI survey has certain limitations, as it includes a limited set of questions for each management practice and does not provide a large dataset for developed economies for comparative analysis. Therefore, further studies analyzing quality management practices using wider definitions of management are needed. These would help to establish the direct and indirect links between management practices and innovation output of different firms. For example, in cases of small firms, innovation in management can serve as a substitute for investments in $R \& D$ (Rammer, Czarnitzki, and Spielkamp 2009). The results of this paper call for further empirical research:

1. Can this result be confirmed for emerging countries if a stricter definition of management quality practices is applied?

2. Does this result hold for developed countries? A comparative study would allow us to study whether business environment factors intensify or weaken the positive effects of management quality.

3. Can the effects of management quality on innovation output be indirect through the innovation input? This hypothesis would be consistent with Cantner and Joel's (2007) findings that direct effects of knowledge management on innovation success are not significant, while the indirect impact through innovation input and cooperation is sizable.

4. Is it possible to confirm a direct causal relationship between improvement of 
management quality and innovation?

\section{References}

Adams, Richard, John Bessant, and Robert Phelps. 2006. "Innovation management measurement: A review." International Journal of Management Reviews 8 (1): 21-47 (March).

Audretsch, David B., and Maryann P. Feldman. 1996. "R\&D Spillovers and the Geography of Innovation and Production." The American Economic Review 86 (3): 630-640 (June).

Birkinshaw, Julian, Gary Hamel, and Michael J. Mol. 2008. "Management Innovation." Academy of Management Review 33 (4): 825-845 (October).

Bloom, Nicholas, Erik Brynjolfsson, Lucia Foster, Ron S. Jarmin, Megha Patnaik, Saporta Eksten, Itay, Van Reenen, and John. 2014a, March. "IT and Management in America." SSRN Scholarly Paper ID 2444907, Social Science Research Network, Rochester, NY.

Bloom, Nicholas, Renata Lemos, Raffaella Sadun, Daniela Scur, and John Van Reenen. 2014b. "Jeea-Fbbva Lecture 2013: The New Empirical Economics of Management." Journal of the European Economic Association 12 (4): 835-876 (August).

Bloom, Nicholas, and John Van Reenen. 2010. "Why Do Management Practices Differ across Firms and Countries?" The Journal of Economic Perspectives 24 (1): 203-224 (January).

Bloom, Nicholas, Helena Schweiger, and John Van Reenen. 2012. "The land that lean manufacturing forgot?" Economics of Transition 20 (4): 593-635 (October). 
Bloom, Nick, and John Van Reenen. 2006, May. "Measuring and Explaining Management Practices Across Firms and Countries." Working Paper 12216, National Bureau of Economic Research.

Cantner, Uwe, and Kristin Joel. 2007, November. "Functional Chains of Knowledge Management - Effects on Firms' Innovative Performance." SSRN Scholarly Paper ID 1027561, Social Science Research Network, Rochester, NY.

Clark, Kim B, and Takahiro Fujimoto. 1989. "Lead time in automobile product development explaining the Japanese advantage." Journal of Engineering and Technology Management 6 (1): 25-58 (September).

Crepon, Bruno, Emmanuel Duguet, and Jacques Mairesse. 1998. "Research, Innovation And Productivity: An Econometric Analysis At The Firm Level." Economics of Innovation and New Technology 7 (2): 115-158 (January).

Dakhli, Mourad, and Dirk De Clercq. 2004. "Human capital, social capital, and innovation: a multi-country study." Entrepreneurship \& Regional Development 16 (2): 107-128 (March).

Earl, Louis, and Fred Gault. 2004, April. "Knowledge Management: Size Matters." In Measuring Knowledge Management in the Business Sector: First Steps, 169186. OECD.

Elche-Hotelano, Dioni. 2011. "Sources of knowledge, investments and appropriability as determinants of innovation: An empirical study in service firms." Innovation 13 (2): 220-235 (August).

Griffin, Abbie, and John R. Hauser. 1996. "Integrating R\&D and Marketing: A Review and Analysis of the Literature." Journal of Product Innovation Management 13 (3): 191-215 (May).

Guadalupe, Maria, Olga Kuzmina, and Catherine Thomas. 2012. "Innovation and Foreign Ownership." American Economic Review 102 (7): 3594-3627. 
Hamel, Gary. 2006. "The Why, What, and How of Management Innovation." Harward Business Review 84 (2): 72-84.

Hayes, Robert H., Steven C. Wheelwright, and Kim B. Clark. 1988. Dynamic Manufacturing: Creating the Learning Organization. Simon and Schuster.

Helper, Susan, and Rebecca Henderson. 2014. "Management Practices, Relational Contracts, and the Decline of General Motors." Journal of Economic Perspectives 28 (1): 49-72.

Huergo, Elena, and Jordi Jaumandreu. 2004. "How Does Probability of Innovation Change with Firm Age?" Small Business Economics 22 (3-4): 193-207 (April).

Kim, Dong-Young, Vinod Kumar, and Uma Kumar. 2012. "Relationship between quality management practices and innovation." Journal of Operations Management 30 (4): 295-315 (May).

Kim, Linsu. 1997. Imitation to Innovation: The Dynamics of Korea's Technological Learning. Harvard Business Press.

Kremp, Elisabeth, and Jacques Mairesse. 2004, January. "Knowledge Management, Innovation, and Productivity: A Firm Level Exploration Based on French Manufacturing CIS3 Data." Working Paper 10237, National Bureau of Economic Research.

Laursen, Keld, and Nicolai J. Foss. 2003. "New human resource management practices, complementarities and the impact on innovation performance." Cambridge Journal of Economics 27 (2): 243-263 (March).

Lerner, Josh, and Julie Wulf. 2007. "Innovation and Incentives: Evidence from Corporate R\&D." Review of Economics and Statistics 89 (4): 634-644 (October). 
Liker, Jeffrey. 2004, January. The Toyota Way: 14 Management Principles from the World's Greatest Manufacturer. 1 edition. New York: McGraw-Hill Education. Mairesse, Jacques, and Pierre Mohnen. 2010. "Using Innovation Surveys for Econometric Analysis." In Handbook of the Economics of Innovation, edited by Bronwyn H. Hall and Nathan Rosenberg, Volume 2 of Handbook of the Economics of Innovation, Volume 2, 1129-1155. North-Holland.

Makri, Marianna, Peter J. Lane, and Luis R. Gomez-Mejia. 2006. "CEO incentives, innovation, and performance in technology-intensive firms: a reconciliation of outcome and behavior-based incentive schemes." Strategic Management Journal 27 (11): 1057-1080 (November).

Mohnen, Pierre, and Bronwyn H. Hall. 2014. "Innovation and Productivity: An Update." Eurasian Business Review 3 (1): 47-65 (August).

Mohnen, Pierre, Jacques Mairesse, and Marcel Dagenais. 2006. "Innovativity: A comparison across seven European countries." Economics of Innovation and New Technology 15 (4-5): 391-413 (June).

Mohnen, P., and Dagenais, M. 2002. "Towards an Innovation Intensity Index. The Case of CIS-I in Denmark and Ireland." In Innovation and Firm Performance. Econometric Explorations of Survey Data, edited by P. Mohnen and A. Kleinknecht. Palgrave.

Mol, Michael J., and Julian Birkinshaw. 2009. "The sources of management innovation: When firms introduce new management practices." Journal of Business Research 62 (12): 1269-1280 (December).

Montoya-Weiss, Mitzi M., and Roger Calantone. 1994. "Determinants of New Product Performance: A Review and Meta-Analysis." Journal of Product Innovation Management 11 (5): 397-417 (November). 
Rammer, Christian, Dirk Czarnitzki, and Alfred Spielkamp. 2009. "Innovation success of non-R\&D-performers: substituting technology by management in SMEs." Small Business Economics 33 (1): 35-58 (March).

Schweiger, Helena, and Guido Friebel. 2013. "Management Quality, Ownership, Firm Performance and Market Pressure in Russia." Open Economies Review 24 (4): 763-788 (February).

Soskice, David. 1997. "German technology policy, innovation, and national institutional frameworks." Industry and Innovation 4 (1): 75-96 (June).

Teece, David, and Gary Pisano. 1994. "The Dynamic Capabilities of Firms: an Introduction." Industrial and Corporate Change 3 (3): 537-556 (January).

Teece, David J. 1986. "Profiting from technological innovation: Implications for integration, collaboration, licensing and public policy." Research Policy 15 (6): 285-305 (December).

Trott, Paul. 2008. Innovation Management and New Product Development. Pearson Education.

Van der Panne, Gerben, Cees van Beers, and Alfred Kleinknecht. 2003. "Success and Failure of Innovation: A Literature Review." International Journal of Innovation Management 07 (03): 309-338 (September).

Walker, Richard M., Fariborz Damanpour, and Carlos A. Devece. 2010. "Management Innovation and Organizational Performance: The Mediating Effect of Performance Management." Journal of Public Administration Research and Theory, August, 1-20. 


\section{Appendices}

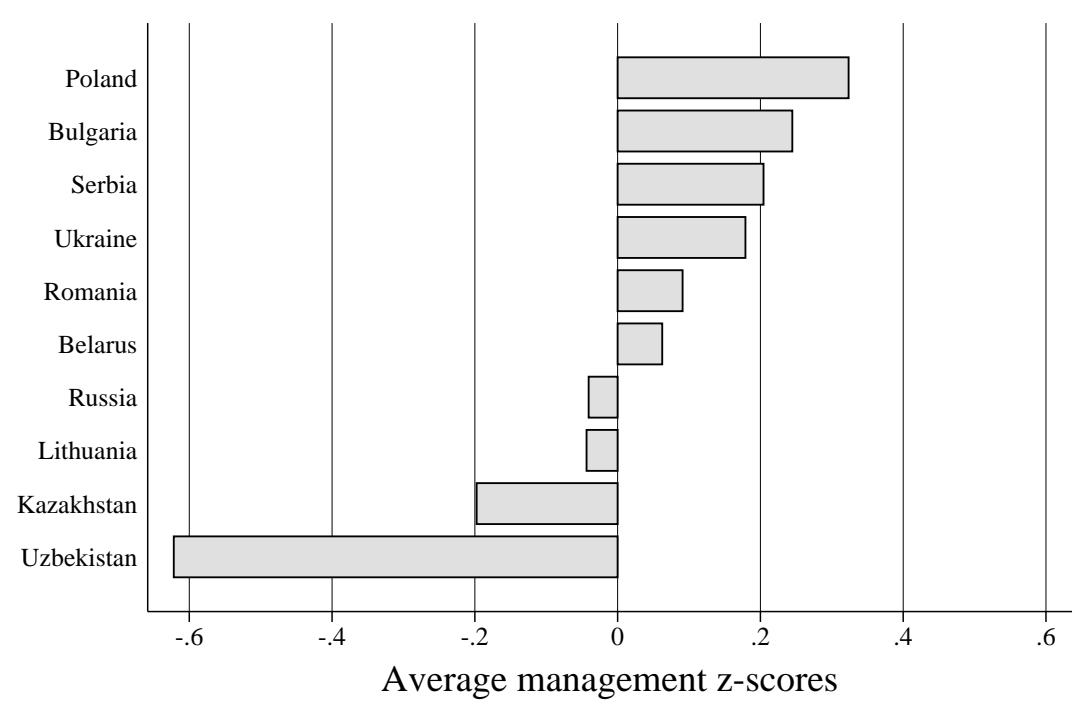

Figure 2: Management scores across countries by average management z-score

Table 2: Summary Statistics: Main Variables

\begin{tabular}{lccccc}
\hline \hline & $(1)$ & & & & \\
& count & $\min$ & $\max$ & $\operatorname{mean}$ & sd \\
\hline Management z-score & 834 & -4.008 & 1.841 & -0.023 & 1.032 \\
Operations z-score & 834 & -4.497 & 0.814 & -0.001 & 0.995 \\
Monitoring z-score & 834 & -2.433 & 1.142 & -0.028 & 0.676 \\
Targeting z-score & 834 & -1.972 & 1.332 & -0.018 & 1.005 \\
Incentives z-score & 834 & -2.448 & 0.723 & -0.025 & 0.680 \\
ln(R\&D spending+1) & 699 & 0 & 1.795 & 0.065 & 0.214 \\
R\&D & 834 & 0 & 1 & 0.376 & 0.485 \\
New products introduced & 832 & 0 & 1 & 0.708 & 0.455 \\
\hline \hline
\end{tabular}




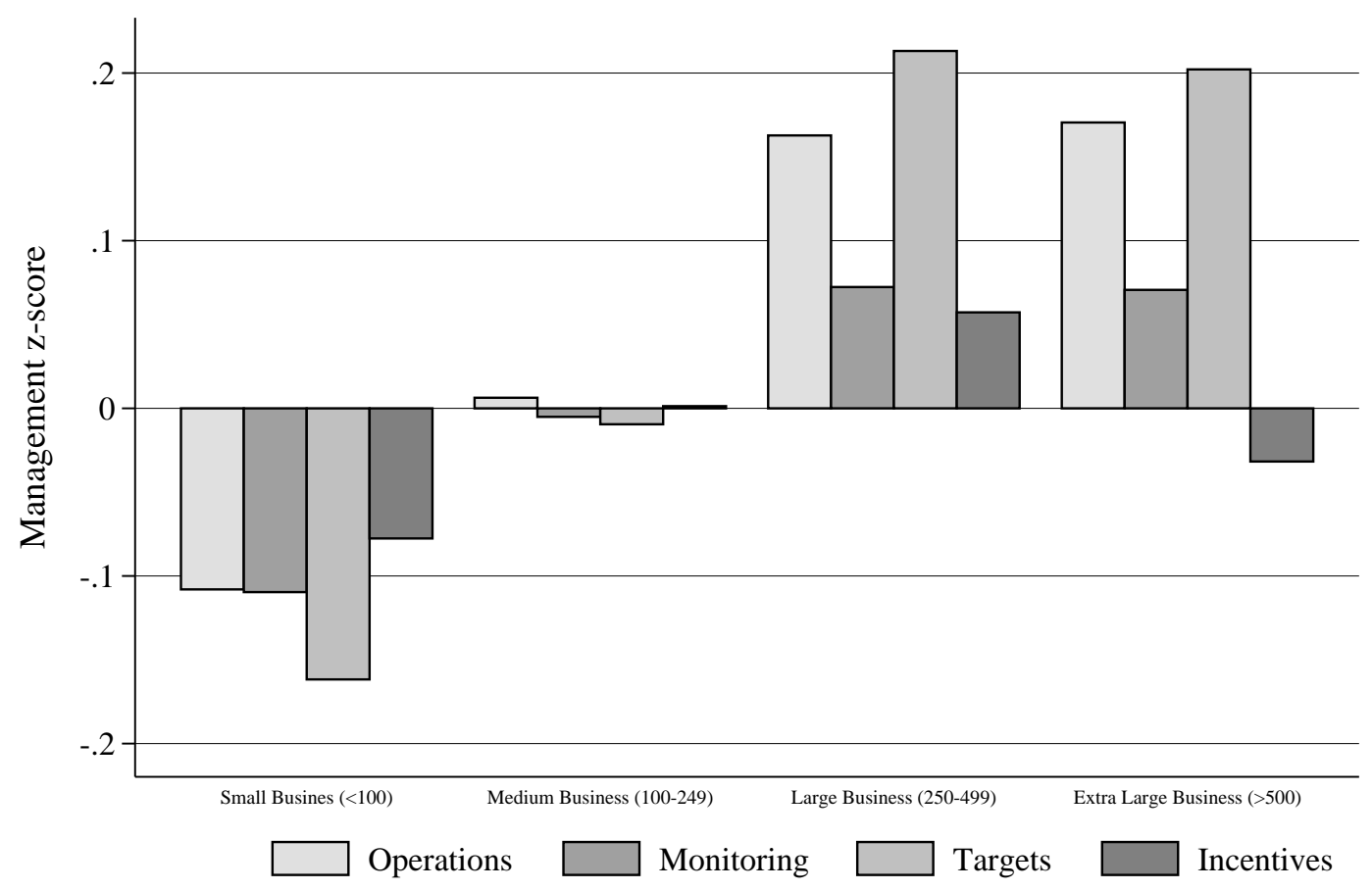

Figure 3: Diffusion of management practices by firm size
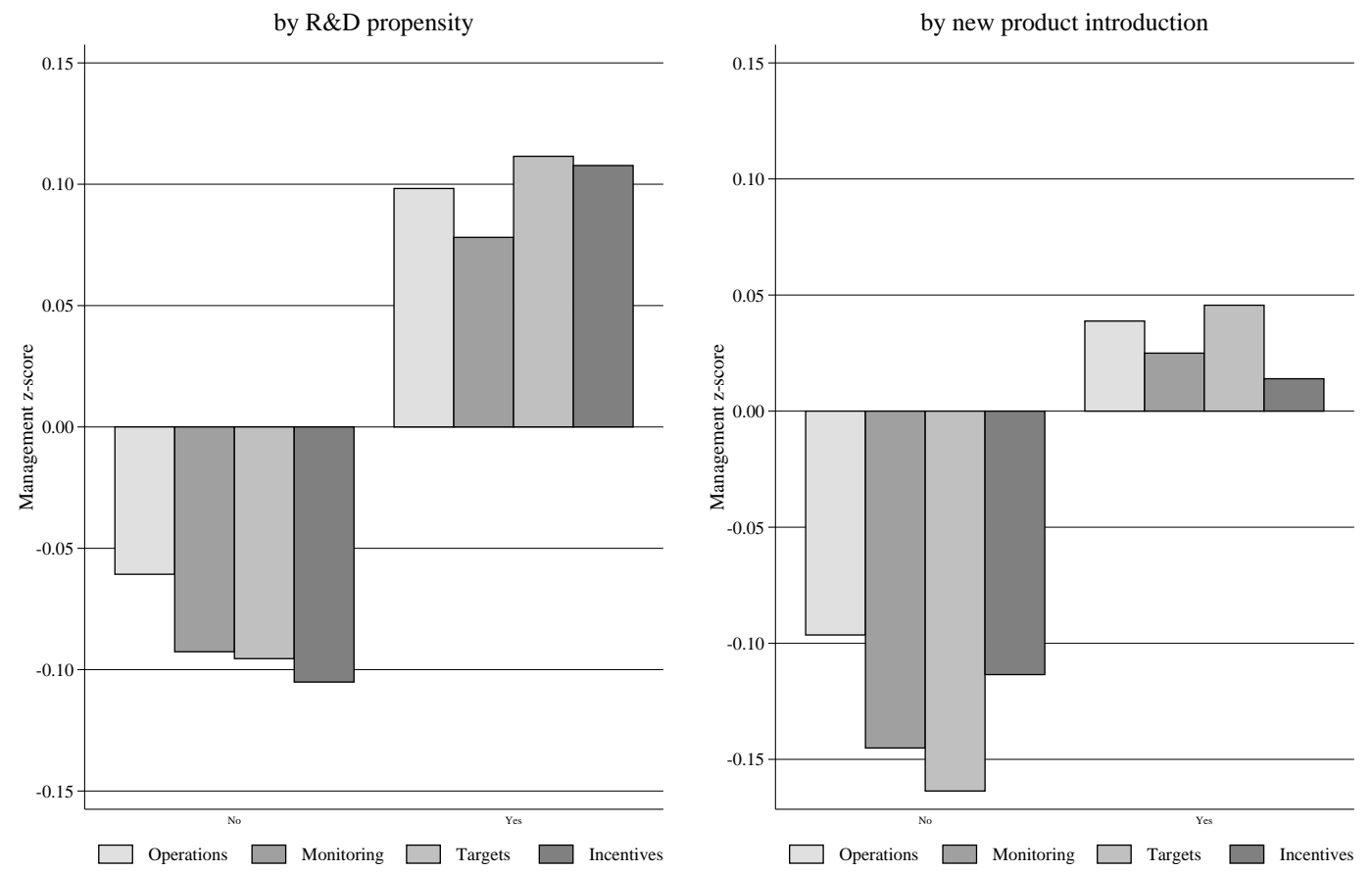

Figure 4: Diffusion of management practices by $R \& D$ propensity and new product introduction 
Table 3: Summary Statistics: Controls

\begin{tabular}{lccccc}
\hline \hline & $(1)$ & & & & \\
& count & min & max & mean & 0.844 \\
\hline Ln(Labour) & 834 & 3.401 & 7.937 & 4.944 & 0.275 \\
Higher education (share) & 834 & 0 & 1 & 0.223 \\
Ln(Firm's Age) & 834 & 0 & 5.342 & 3.048 & 0.948 \\
Shareholding company (traded) & 834 & 0 & 1 & 0.259 & 0.438 \\
Ln(Perm. FT emp. weekly hours) & 834 & 3.178 & 4.094 & 3.715 & 0.088 \\
Capital city & 834 & 0 & 1 & 0.291 & 0.455 \\
Foreign (largest owner) & 834 & 0 & 1 & 0.082 & 0.274 \\
High-speed Internet & 834 & 0 & 1 & 0.829 & 0.377 \\
Pressure from imports & 834 & 0 & 1 & 0.683 & 0.465 \\
Ln(Fixed Assets, 2008) & 504 & -9.390 & 5.522 & 1.536 & 1.768 \\
ROTA (2008) & 503 & -79.48 & 75.91 & 3.614 & 16.519 \\
\hline \hline
\end{tabular}

Table 4: Summary Statistics: Countries

\begin{tabular}{clcc}
\hline \hline \multicolumn{1}{c}{ EU status } & Country & frequency & percent \\
\hline Non-EU countries & Belarus & 46 & 5.52 \\
& Kazakhstan & 97 & 11.63 \\
& Russia & 242 & 29.02 \\
& Ukraine & 93 & 11.15 \\
& Uzbekistan & 88 & 10.55 \\
\hline EU countries & Bulgaria & 53 & 6.35 \\
& Lithuania & 41 & 4.92 \\
& Poland & 39 & 4.68 \\
& Romania & 55 & 6.59 \\
& Serbia & 80 & 9.59 \\
\hline Total & 834 & 100.00 & \\
\hline \hline
\end{tabular}

Table 5: Summary Statistics: Years

\begin{tabular}{lcc}
\hline \hline & $(1)$ & \\
& frequency & percent \\
\hline 2008 & 474 & 56.83 \\
$2009-2010$ & 360 & 43.17 \\
\hline Total & 834 & 100.00 \\
\hline \hline
\end{tabular}


Table 6: Summary Statistics: Industries

\begin{tabular}{lcc}
\hline \hline & $(1)$ & \\
& percent \\
\hline Other Manufacturing & 237 & 28.42 \\
Food & 179 & 21.46 \\
Textiles & 28 & 3.36 \\
Garments & 43 & 5.16 \\
Chemicals & 33 & 3.96 \\
Plastics and Rubber & 34 & 4.08 \\
Non Metallic Mineral Products & 63 & 7.55 \\
Basic Metals & 7 & 0.84 \\
Fabricate Metal Products & 107 & 12.83 \\
Machinery and Equipment & 68 & 8.15 \\
Electronics & 35 & 4.20 \\
\hline Total & 834 & 100.00 \\
\hline \hline
\end{tabular}

Table 7: Parewise comparison at 25th percentile (mgmz) and median(mgmz)

\begin{tabular}{lcccc}
\hline \hline & $\mathrm{b}$ & $\mathrm{se}$ & $\mathrm{z}$ & $\mathrm{p}$ \\
\hline Model (1). R\&D propensity & & & & \\
1. Management z-score (25th percentile) & 0.316 & 0.0209 & 15.110 & 0.000 \\
2. Management z-score (median) & 0.360 & 0.0188 & 19.198 & 0.000 \\
Pairwise comparison 1. and 2. & 0.045 & 0.014 & 3.16 & 0.002 \\
\hline Model (2). R\&D intensity & & & & \\
3. Management z-score (25th percentile) & -0.444 & 0.0547 & -8.129 & 0.000 \\
4. Management z-score (median) & -0.388 & 0.0463 & -8.372 & 0.000 \\
Pairwise comparison 3. and 4. & 0.057 & 0.021 & 2.73 & 0.006 \\
\hline Model (3). New product & & & & \\
5. Management z-score (25th percentile) & 0.715 & 0.0836 & 8.546 & 0.000 \\
6. Management z-score (median) & 0.746 & 0.0582 & 12.816 & 0.000 \\
Pairwise comparison 5. and 6. & 0.008 & 0.030 & 0.26 & 0.797 \\
\hline \hline
\end{tabular}

Table 8: Specification tests for exclusion of four individual management practices

\begin{tabular}{lcccc}
\hline \hline & $\mathrm{N}$ & LR test & AIC & BIC \\
\hline Model (1) R\&D (constrained) & 834 & & 1037.03 & 1188.27 \\
Model (2) R\&D (unconstrained) & 834 & \multirow{2}{*}{$10.87^{* *}$} & 1032.17 & 1197.58 \\
Model (3) R\&D spen. (constrained) & 699 & & 691.98 & 833.01 \\
Model (4) R\&D spen. (unconstrained) & 699 & \multirow{2}{*}{$14.09^{* * *}$} & 685.89 & 845.12 \\
Model (5) New product (constrained) & 387 & & 466.85 & 581.64 \\
Model (6) New product (unconstrained) & 387 & 5.92 & 468.93 & 599.55 \\
\hline \hline
\end{tabular}




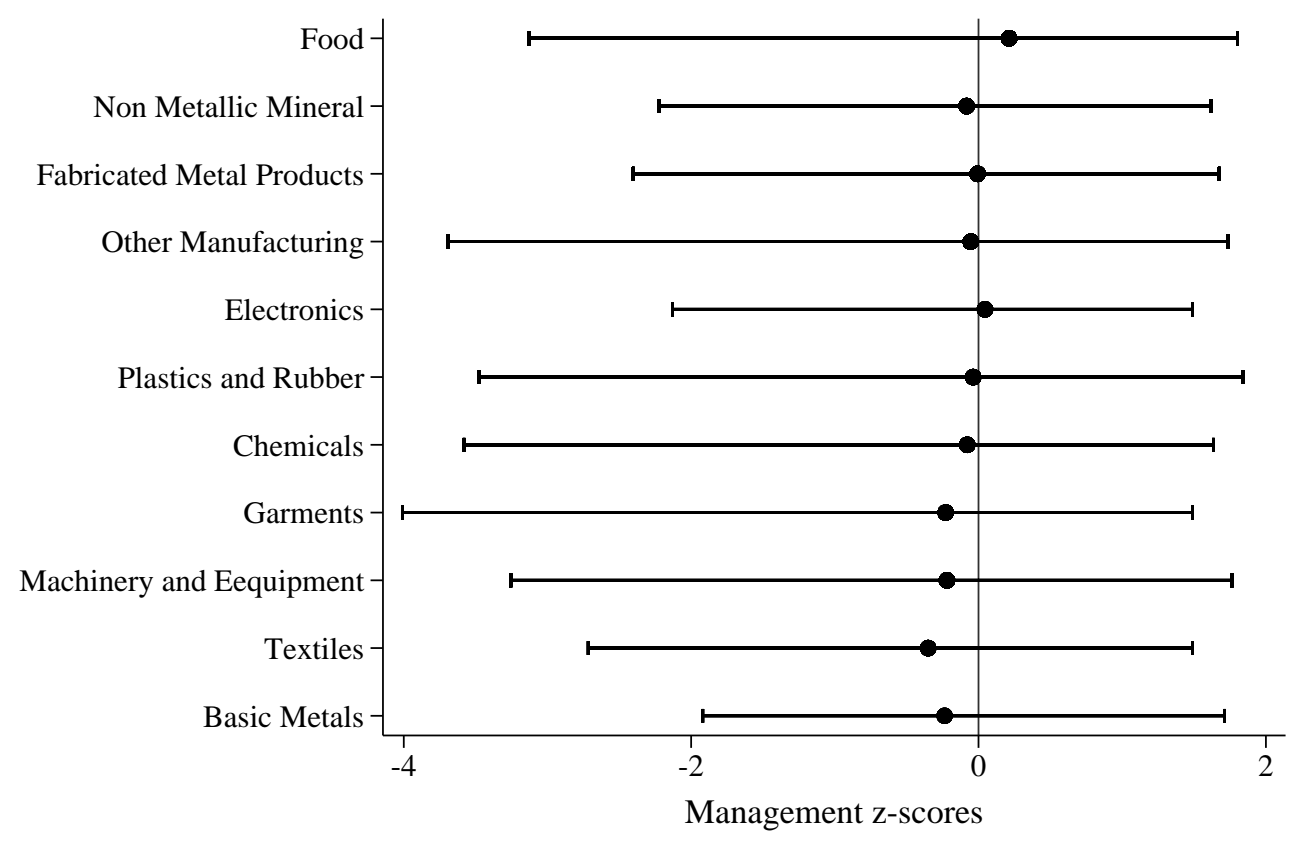

Figure 5: Diffusion of management quality scores by industries 
Table 9: Management quality, normalized by industries

\begin{tabular}{|c|c|c|c|c|c|c|}
\hline & \multicolumn{2}{|c|}{ logit $(\mathrm{R} \& \mathrm{D})$} & \multicolumn{2}{|c|}{ tobit (R\&D) spending } & \multicolumn{2}{|c|}{ "logit (New product) } \\
\hline & (1) & $(2)$ & $(3)$ & $(4)$ & $(5)$ & $(6)$ \\
\hline Management z-score & $\begin{array}{l}0.287^{* * *} \\
(0.098)\end{array}$ & & $\begin{array}{c}0.061^{* *} \\
(0.030)\end{array}$ & & $\begin{array}{c}0.364^{* *} \\
(0.164)\end{array}$ & \\
\hline Operations z-score & & $\begin{array}{l}-0.043 \\
(0.087)\end{array}$ & & $\begin{array}{l}-0.008 \\
(0.030)\end{array}$ & & $\begin{array}{c}0.113 \\
(0.141)\end{array}$ \\
\hline Incentives z-score & & $\begin{array}{l}0.401^{* * *} \\
(0.133)\end{array}$ & & $\begin{array}{c}0.095^{* * *} \\
(0.036)\end{array}$ & & $\begin{array}{c}0.036 \\
(0.212)\end{array}$ \\
\hline Targeting z-score & & $\begin{array}{c}0.043 \\
(0.081)\end{array}$ & & $\begin{array}{c}0.009 \\
(0.025)\end{array}$ & & $\begin{array}{l}-0.041 \\
(0.140)\end{array}$ \\
\hline Monitoring z-score & & $\begin{array}{c}0.315^{* *} \\
(0.143)\end{array}$ & & $\begin{array}{l}0.108^{* *} \\
(0.046)\end{array}$ & & $\begin{array}{c}0.438^{* *} \\
(0.205)\end{array}$ \\
\hline $\mathrm{EU}$ & $\begin{array}{c}0.656^{*} \\
(0.369)\end{array}$ & & $\begin{array}{c}0.298^{* *} \\
(0.127)\end{array}$ & & $\begin{array}{c}0.694 \\
(0.937)\end{array}$ & \\
\hline $\mathrm{EU} \times$ Management $\mathrm{z}$-score & $\begin{array}{c}-0.121 \\
(0.166)\end{array}$ & & $\begin{array}{c}0.028 \\
(0.052)\end{array}$ & & $\begin{array}{c}-0.288 \\
(0.255)\end{array}$ & \\
\hline Ln(Labour) & $\begin{array}{l}0.329^{* * *} \\
(0.106)\end{array}$ & $\begin{array}{l}0.350^{* * *} \\
(0.105)\end{array}$ & $\begin{array}{c}0.036 \\
(0.032)\end{array}$ & $\begin{array}{c}0.038 \\
(0.032)\end{array}$ & $\begin{array}{c}0.295^{*} \\
(0.176)\end{array}$ & $\begin{array}{c}0.317^{*} \\
(0.175)\end{array}$ \\
\hline Higher education (share) & $\begin{array}{c}0.472 \\
(0.385)\end{array}$ & $\begin{array}{c}0.392 \\
(0.386)\end{array}$ & $\begin{array}{c}0.133 \\
(0.115)\end{array}$ & $\begin{array}{c}0.127 \\
(0.116)\end{array}$ & $\begin{array}{c}0.391 \\
(0.673)\end{array}$ & $\begin{array}{c}0.494 \\
(0.647)\end{array}$ \\
\hline Ln(R\&D spending) & & & & & $\begin{array}{c}6.447 \\
(3.929)\end{array}$ & $\begin{array}{c}5.910 \\
(3.852)\end{array}$ \\
\hline $\operatorname{Ln}(\mathrm{R} \& \mathrm{D}$ spending $) \times \mathrm{z}$-score & & & & & $\begin{array}{l}-2.064 \\
(2.524)\end{array}$ & \\
\hline Pressure from Imports & $\begin{array}{l}0.699^{* * *} \\
(0.181)\end{array}$ & $\begin{array}{l}0.670^{* * *} \\
(0.181)\end{array}$ & $\begin{array}{c}0.212^{* * *} \\
(0.055)\end{array}$ & $\begin{array}{c}0.198^{* * *} \\
(0.056)\end{array}$ & $\begin{array}{l}0.610^{* *} \\
(0.255)\end{array}$ & $\begin{array}{l}0.541^{* *} \\
(0.259)\end{array}$ \\
\hline High-speed Internet & $\begin{array}{l}0.744^{* * *} \\
(0.267)\end{array}$ & $\begin{array}{l}0.689^{* *} \\
(0.271)\end{array}$ & $\begin{array}{l}0.170^{* *} \\
(0.078)\end{array}$ & $\begin{array}{l}0.165^{* *} \\
(0.078)\end{array}$ & $\begin{array}{c}0.042 \\
(0.392)\end{array}$ & $\begin{array}{l}-0.005 \\
(0.389)\end{array}$ \\
\hline Year (2009-2010) & $\begin{array}{l}-0.493^{* *} \\
(0.196)\end{array}$ & $\begin{array}{c}-0.509^{* *} \\
(0.198)\end{array}$ & $\begin{array}{c}-0.217^{* * *} \\
(0.065)\end{array}$ & $\begin{array}{c}-0.231^{* * *} \\
(0.065)\end{array}$ & $\begin{array}{c}-0.688^{* *} \\
(0.297)\end{array}$ & $\begin{array}{c}-0.723^{* *} \\
(0.302)\end{array}$ \\
\hline$\sigma$ & & & $\begin{array}{c}0.486^{* * *} \\
(0.043)\end{array}$ & $\begin{array}{c}0.484^{* * *} \\
(0.043)\end{array}$ & & \\
\hline Country fixed effects & Yes & Yes & Yes & Yes & Yes & Yes \\
\hline Industry fixed effects & Yes & Yes & Yes & Yes & Yes & Yes \\
\hline Pseudo $R^{2}$ & 0.120 & 0.129 & 0.135 & 0.145 & 0.170 & 0.172 \\
\hline Prob $>C h i^{2}$ & 0.000 & 0.000 & 0.001 & 0.000 & 0.027 & 0.052 \\
\hline Observations & 834 & 834 & 699 & 699 & 387 & 387 \\
\hline
\end{tabular}

Raw coefficients. Robust standard errors in parentheses

Source: Author's calculations based on the EBRD and World Bank MOI survey.

${ }^{*} p<0.10,{ }^{* *} p<0.05,{ }^{* * *} p<0.01$ 
Table 10: Quality Assymetries

\begin{tabular}{|c|c|c|c|c|c|c|}
\hline & \multicolumn{2}{|c|}{ logit (R\&D) } & \multicolumn{2}{|c|}{ tobit (R\&D) spending } & \multicolumn{2}{|c|}{ "logit (New product) } \\
\hline & (1) & (2) & $(3)$ & (4) & $(5)$ & $(6)$ \\
\hline Management z-score $<0$ & $\begin{array}{l}0.457^{* *} \\
(0.193)\end{array}$ & & $\begin{array}{c}0.202^{* * *} \\
(0.064)\end{array}$ & & $\begin{array}{c}0.131 \\
(0.233)\end{array}$ & \\
\hline Management z-score $>0$ & $\begin{array}{l}-0.107 \\
(0.206)\end{array}$ & & $\begin{array}{c}0.001 \\
(0.066)\end{array}$ & & $\begin{array}{c}0.436 \\
(0.336)\end{array}$ & \\
\hline Operations z-score $<0$ & & $\begin{array}{c}0.190 \\
(0.279)\end{array}$ & & $\begin{array}{c}0.087 \\
(0.086)\end{array}$ & & $\begin{array}{c}0.045 \\
(0.403)\end{array}$ \\
\hline Operations z-score $>0$ & & $\begin{array}{l}-0.392 \\
(0.425)\end{array}$ & & $\begin{array}{l}-0.149 \\
(0.131)\end{array}$ & & $\begin{array}{c}0.232 \\
(0.620)\end{array}$ \\
\hline Incentives z-score $<0$ & & $\begin{array}{l}0.525^{* *} \\
(0.235)\end{array}$ & & $\begin{array}{c}0.274^{* * *} \\
(0.079)\end{array}$ & & $\begin{array}{c}0.024 \\
(0.349)\end{array}$ \\
\hline Incentives z-score $>0$ & & $\begin{array}{c}0.209 \\
(0.331)\end{array}$ & & $\begin{array}{c}-0.195^{*} \\
(0.107)\end{array}$ & & $\begin{array}{c}0.069 \\
(0.495)\end{array}$ \\
\hline Targeting z-score $<0$ & & $\begin{array}{l}0.438^{* *} \\
(0.202)\end{array}$ & & $\begin{array}{l}0.108^{*} \\
(0.061)\end{array}$ & & $\begin{array}{c}0.145 \\
(0.349)\end{array}$ \\
\hline Targeting z-score $>0$ & & $\begin{array}{l}-0.283 \\
(0.181)\end{array}$ & & $\begin{array}{l}-0.077 \\
(0.057)\end{array}$ & & $\begin{array}{l}-0.210 \\
(0.304)\end{array}$ \\
\hline Monitoring z-score $<0$ & & $\begin{array}{c}0.167 \\
(0.202)\end{array}$ & & $\begin{array}{c}0.057 \\
(0.057)\end{array}$ & & $\begin{array}{c}0.411 \\
(0.289)\end{array}$ \\
\hline Monitoring z-score $>0$ & & $\begin{array}{l}0.517^{*} \\
(0.311)\end{array}$ & & $\begin{array}{l}0.188^{*} \\
(0.103)\end{array}$ & & $\begin{array}{c}0.394 \\
(0.527)\end{array}$ \\
\hline Non-EU $\times$ z-score & $\begin{array}{c}0.072 \\
(0.175)\end{array}$ & & $\begin{array}{c}-0.058 \\
(0.056)\end{array}$ & & & \\
\hline $\mathrm{EU}$ & $\begin{array}{l}0.648^{*} \\
(0.369)\end{array}$ & & $\begin{array}{l}0.298^{* *} \\
(0.125)\end{array}$ & & $\begin{array}{c}0.599 \\
(0.950)\end{array}$ & \\
\hline Ln(Labour) & $\begin{array}{c}0.328^{* * *} \\
(0.106)\end{array}$ & $\begin{array}{c}0.340^{* * *} \\
(0.105)\end{array}$ & $\begin{array}{c}0.037 \\
(0.032)\end{array}$ & $\begin{array}{c}0.034 \\
(0.031)\end{array}$ & $\begin{array}{l}0.290^{*} \\
(0.175)\end{array}$ & $\begin{array}{c}0.309^{*} \\
(0.175)\end{array}$ \\
\hline Higher education (share) & $\begin{array}{c}0.448 \\
(0.386)\end{array}$ & $\begin{array}{c}0.336 \\
(0.395)\end{array}$ & $\begin{array}{c}0.117 \\
(0.113)\end{array}$ & $\begin{array}{c}0.112 \\
(0.120)\end{array}$ & $\begin{array}{c}0.357 \\
(0.663)\end{array}$ & $\begin{array}{c}0.496 \\
(0.652)\end{array}$ \\
\hline Ln(R\&D spending) & & & & & $\begin{array}{c}6.589^{*} \\
(3.800)\end{array}$ & $\begin{array}{c}5.794 \\
(3.785)\end{array}$ \\
\hline $\operatorname{Ln}(\mathrm{R} \& \mathrm{D}$ spending $) \times \mathrm{z}$-score & & & & & $\begin{array}{l}-2.702 \\
(2.533)\end{array}$ & \\
\hline Pressure from Imports & $\begin{array}{c}0.693^{* * *} \\
(0.181)\end{array}$ & $\begin{array}{c}0.661^{* * *} \\
(0.183)\end{array}$ & $\begin{array}{c}0.212^{* * *} \\
(0.055)\end{array}$ & $\begin{array}{c}0.189^{* * *} \\
(0.055)\end{array}$ & $\begin{array}{l}0.607^{* *} \\
(0.257)\end{array}$ & $\begin{array}{c}0.523^{* *} \\
(0.262)\end{array}$ \\
\hline High-speed Internet & $\begin{array}{c}0.753^{* * *} \\
(0.268)\end{array}$ & $\begin{array}{l}0.702^{* *} \\
(0.275)\end{array}$ & $\begin{array}{l}0.162^{* *} \\
(0.078)\end{array}$ & $\begin{array}{l}0.176^{* *} \\
(0.079)\end{array}$ & $\begin{array}{c}0.050 \\
(0.389)\end{array}$ & $\begin{array}{l}-0.030 \\
(0.392)\end{array}$ \\
\hline Year (2009-2010) & $\begin{array}{c}-0.510^{* * *} \\
(0.195)\end{array}$ & $\begin{array}{c}-0.532^{* * *} \\
(0.200)\end{array}$ & $\begin{array}{c}-0.224^{* * *} \\
(0.065)\end{array}$ & $\begin{array}{c}-0.241^{* * *} \\
(0.067)\end{array}$ & $\begin{array}{c}-0.652^{* *} \\
(0.294)\end{array}$ & $\begin{array}{c}-0.724^{* *} \\
(0.301)\end{array}$ \\
\hline$\sigma$ & & & $\begin{array}{c}0.484^{* * *} \\
(0.043)\end{array}$ & $\begin{array}{c}0.473^{* * *} \\
(0.040)\end{array}$ & & \\
\hline Country fixed effects & Yes & Yes & Yes & Yes & Yes & Yes \\
\hline Industry fixed effects & Yes & Yes & Yes & Yes & Yes & Yes \\
\hline Pseudo $R^{2}$ & 0.123 & 0.134 & 0.141 & 0.164 & 0.168 & 0.173 \\
\hline Prob $>F$ & 0.000 & 0.000 & 0.000 & 0.001 & 0.046 & 0.100 \\
\hline Observations & 834 & 834 & 699 & 699 & 387 & 387 \\
\hline
\end{tabular}

Raw coefficients. Robust standard errors in parentheses.

Source: Author's calculations based on the EBRD and World Bank MOI survey.

${ }^{*} p<0.10,{ }^{* *} p<0.05,{ }^{* * *} p<0.01$ 
Table 11: Operations R.1. What normally happens when a process problem arises, for example, machinery break-down human errors or failures in communication?

\begin{tabular}{lcc}
\hline \hline & $\begin{array}{c}\text { Score in } \\
\text { questionnaire }\end{array}$ & $\begin{array}{c}\text { Management } \\
\text { score }\end{array}$ \\
\hline Nothing is done about it. & 1 & 1 \\
We fix it but do not take further measures. & 2 & 2 \\
$\begin{array}{l}\text { We fix it and we take measures to make sure } \\
\text { that it does not happen again. }\end{array}$ & 3 & 3 \\
$\begin{array}{l}\text { We fix it and we take measures to make sure } \\
\text { that it does not happen again and we also have }\end{array}$ & 4 & 4 \\
$\begin{array}{l}\text { a continuous improvement process to anticipate } \\
\text { problems. }\end{array}$ & & \\
$\begin{array}{l}\text { Don't know } \\
\text { Refusal }\end{array}$ & -9 &. \\
\hline \hline
\end{tabular}

Table 12: Targets R.4. What is the timescale of this establishment's production targets for the main product?

\begin{tabular}{lcc}
\hline \hline & $\begin{array}{l}\text { Score in } \\
\text { questionnaire }\end{array}$ & $\begin{array}{c}\text { Management } \\
\text { score }\end{array}$ \\
\hline $\begin{array}{l}\text { The main focus is on short-term (less than one year) } \\
\text { production targets for the main product. }\end{array}$ & 1 & 2 \\
$\begin{array}{l}\text { There are short- and long-term (more than three years) } \\
\text { production targets for the main product, }\end{array}$ & 2 & 3 \\
$\begin{array}{l}\text { but they are set independently. } \\
\text { There are integrated short- and long-term production }\end{array}$ & 3 & 4 \\
$\begin{array}{l}\text { targets for the main product. } \\
\text { There are no production targets set for the main }\end{array}$ & 4 & 1 \\
product. & -9 & 1 \\
$\begin{array}{l}\text { Don't know } \\
\text { Refusal }\end{array}$ & -8 & . \\
\hline \hline
\end{tabular}

Table 13: Incentives R.7. How do you reward this establishment's production target achievement?

\begin{tabular}{lcc}
\hline & Score in questionnaire & Management score \\
\hline There are no rewards. & 1 & 1 \\
Only top and middle management & 2 & 2 \\
is rewarded. & 3 & 3 \\
All staff is rewarded. & -9 &. \\
Don't know & -8 &. \\
Refusal & - \\
\hline \hline
\end{tabular}


Table 14: Incentives O.14. Which of the following best corresponds to the main way employees are promoted in this establishment?

\begin{tabular}{lcc}
\hline \hline & $\begin{array}{l}\text { Score in } \\
\text { questionnaire }\end{array}$ & $\begin{array}{l}\text { Management } \\
\text { score }\end{array}$ \\
\hline $\begin{array}{l}\text { Promotions are based solely on individual's } \\
\text { effort and ability. }\end{array}$ & 1 & 3 \\
$\begin{array}{l}\text { Promotions are based partly on individual's } \\
\text { efforts and ability, and partly on other factors }\end{array}$ & 2 & 2 \\
such as tenure (how long they have worked & & \\
at the firm. & & 1 \\
$\begin{array}{l}\text { Promotions are based mainly on factors other } \\
\text { than on individual's effort and ability, }\end{array}$ & 3 & $\cdot$ \\
such as tenure. & 4 & $\cdot$ \\
$\begin{array}{l}\text { Other. } \\
\text { Does not apply }\end{array}$ & -7 & $\cdot$ \\
\hline \hline
\end{tabular}

Table 15: Incentives O.15. Which of the following best corresponds to this establishment's main policy when dealing with employees who do not meet expectations in their position?

\begin{tabular}{lcc}
\hline \hline & $\begin{array}{l}\text { Score in } \\
\text { questionnaire }\end{array}$ & $\begin{array}{c}\text { Management } \\
\text { score }\end{array}$ \\
\hline $\begin{array}{l}\text { They are rarely or never moved from their } \\
\text { position. }\end{array}$ & 1 & 1 \\
$\begin{array}{l}\text { They usually stay in their positions for at least a } \\
\text { year before action is taken. }\end{array}$ & 2 & 2 \\
$\begin{array}{l}\text { They are rapidly helped and re-trained, and } \\
\text { then dismissed if their performance does not }\end{array}$ & 3 & 3 \\
$\begin{array}{l}\text { improve. } \\
\text { Other. }\end{array}$ & 4 & $\cdot$ \\
$\begin{array}{l}\text { Does not apply } \\
\text { Don't know }\end{array}$ & -7 & $\cdot$ \\
\hline \hline
\end{tabular}

Table 16: Monitoring R.2a. How many production performance indicators are monitored in this establishment?

\begin{tabular}{lcc}
\hline \hline & $\begin{array}{l}\text { Score in } \\
\text { questionnaire }\end{array}$ & $\begin{array}{l}\text { Management } \\
\text { score }\end{array}$ \\
\hline None. & 1 & 1 \\
One or two production performance indicators & 2 & 2 \\
(for example, volume and quality). & 3 & 3 \\
More than two production performance indicators. & -9 & 1 \\
Don't know & -8 &. \\
Refusal & & .
\end{tabular}


Table 17: Monitoring R.2b. How frequently are these production performance indicators collected in this establishment?

\begin{tabular}{lcc}
\hline \hline & Score in questionnaire & Management score \\
\hline Yearly & 1 & 1 \\
Quarterly & 2 & 2 \\
Monthly & 3 & 3 \\
Weekly & 4 & 4 \\
Daily & 5 & 5 \\
Hourly & 6 & 6 \\
Don't know & -9 & 1 \\
Never & - & 0 \\
\hline \hline
\end{tabular}

Table 18: Monitoring R.2c. How frequently are production performance indicators shown to factory managers?

\begin{tabular}{lcc}
\hline \hline & Score in questionnaire & Management score \\
\hline Annually & 2 & 2 \\
Semi-annually & 3 & 3 \\
Quarterly & 4 & 4 \\
Monthly & 5 & 5 \\
Weekly & 6 & 6 \\
Daily & 7 & 7 \\
Hourly & 8 & 8 \\
Never & 1 & 1 \\
Other & 10 & depends on answer \\
Don't know & -9 &. \\
\hline \hline
\end{tabular}

Table 19: Monitoring R.2d. How frequently are production performance indicators shown to workers?

\begin{tabular}{lcc}
\hline \hline & Score in questionnaire & Management score \\
\hline Annually & 2 & 2 \\
Semi-annually & 3 & 3 \\
Quarterly & 4 & 4 \\
Monthly & 5 & 5 \\
Weekly & 6 & 6 \\
Daily & 7 & 7 \\
Hourly & 8 & 8 \\
Never & 1 & 1 \\
Other & 10 & depends on answer \\
Don't know & -9 & 1 \\
\hline \hline
\end{tabular}

Table 20: Monitoring R.3. How often are production performance indicators reviewed by top or middle managers?

\begin{tabular}{lcc}
\hline \hline & Score in questionnaire & Management score \\
\hline They are continually reviewed. & 1 & 3 \\
They are periodically reviewed. & 2 & 2 \\
They are rarely reviewed. & 3 & 1 \\
Don't know & -9 & 1 \\
Refusal & -8 &. \\
\hline \hline
\end{tabular}


Table 21: Monitoring R.6. Does this establishment use any production performance indicators to compare different teams of employees in the production line, in different shifts, or similar?

\begin{tabular}{lcc}
\hline \hline & Score in questionnaire & Management score \\
\hline Yes & 1 & 2 \\
No & 2 & 1 \\
Don't know & -9 &. \\
\hline \hline
\end{tabular}




\section{Working Paper Series}

ISSN 1211-3298

Registration No. (Ministry of Culture): E 19443

Individual researchers, as well as the on-line and printed versions of the CERGE-EI Working Papers (including their dissemination) were supported from institutional support RVO 67985998 from Economics Institute of the ASCR, v. v. i.

Specific research support and/or other grants the researchers/publications benefited from are acknowledged at the beginning of the Paper.

(c) Oleg Sidorkin, 2015

All rights reserved. No part of this publication may be reproduced, stored in a retrieval system or transmitted in any form or by any means, electronic, mechanical or photocopying, recording, or otherwise without the prior permission of the publisher.

Published by

Charles University in Prague, Center for Economic Research and Graduate Education (CERGE) and

Economics Institute of the CAS, v. v. i. (EI)

CERGE-El, Politických vězňů 7, 11121 Prague 1, tel.: +420 224005 153, Czech Republic.

Printed by CERGE-EI, Prague

Subscription: CERGE-EI homepage: http://www.cerge-ei.cz

Phone: + 420224005153

Email: office@cerge-ei.cz

Web: http://www.cerge-ei.cz

Editor: Jan Zápal

The paper is available online at http://www.cerge-ei.cz/publications/working_papers/.

ISBN 978-80-7343-362-8 (Univerzita Karlova v Praze, Centrum pro ekonomický výzkum a doktorské studium)

ISBN 978-80-7344-366-5 (Národohospodářský ústav AV ČR, v. v. i.) 
CERGE-EI

P.O.BOX 882

Politických vězňů 7

11121 Praha 1

Czech Republic http://www.cerge-ei.cz 